\title{
COMPARISON OF DIFFERENT SURGICAL PROCEDURES WITH LOCAL INFILTRATION ANALGESIA IN DAY SURGERY
}

\author{
Kata Šakić ${ }^{1,7,}$, Dinko Bagatin ${ }^{2,7}$, Tomica Bagatin $^{3,7}$, Livija Šakić ${ }^{4}$, \\ Vjekoslav Jeleč ${ }^{5}$ and Aleksandar Včev ${ }^{6,7}$
}

${ }^{1}$ Department of Anaesthesiology and Pain therapy at Maxillofacial, General, Plastic,

Reconstructive and Aesthetic Surgery Polyclinic “Bagatin”, Zagreb, Croatia;

${ }^{2}$ Department of General, Plastic, Reconstuctive and Aesthetic Surgery at Maxillofacial, General, Plastic,

Reconstructive and Aesthetic Surgery Polyclinic "Bagatin”, Zagreb, Croatia;

${ }^{3}$ Department of Maxillofacial, Plastic, Reconstuctive and Aesthetic Surgery at Maxillofacial, General, Plastic,

Reconstructive and Aesthetic Surgery Polyclinic “Bagatin”, Zagreb, Croatia;

${ }^{4}$ Department of Anaesthesiology, Reanimathology and Intensive medicine

University hospital "Sveti Duh", Zagreb, Croatia;

${ }^{5}$ Department of Neurosurgery, University hospital Dubrava, Zagreb, Croatia;

${ }^{6}$ Department of Internal medicine, Clinical hospital centar Osijek, Osijek, Croatia;

${ }^{7}$ Faculty of Dental medicine and Health Osijek, Josip Juraj Strossmayer University in Osijek,

Osijek, Croatia;

${ }^{8}$ Catholic University of Croatia, Zagreb, Croatia

\begin{abstract}
SUMMARY - Purpose of this study was assessing of local infiltration analgesia (LIA) with levobupivacaine on the trend of acute postoperative pain and outcome in individuals who underwent rhinoplasty procedure and abdominoplasty performed in general anaesthesia. The research was conducted on 60 patients, of which 30 patients underwent rhinoplasty procedure and the other $30 \mathrm{pa}^{-}$ tients underwent abdominoplasty procedure in general anaesthesia with LIA in "Bagatin" Polyclinic in the time period between 01.01.2014. and 01.01.2017. Postoperative analgesics doses on the same day of surgery were noted in $85 \%$ of participants who underwent an abdominoplasty procedure and in $45 \%$ of participants underwent rhinoplasty procedure. Patients who underwent abdominoplasty were discharged from the facility within 48 hours, while all patients who underwent rhinoplasty procedure were discharged on the same day of the surgery. During the first postoperative day patients who underwent a rhinoplasty procedure did not require analgesics, while only $3 \%$ of patients who underwent an abdominal liposuction procedure required an additional dose of analgesics. The research results had shown, when LIA was performed, the manifestation of acute postoperative pain and vomiting did not lead to prolonged stay in day surgery.
\end{abstract}

Key words: local infiltration analgesia, rhinoplasty, abdominal surgery, day surgery, postoperative pain, clinical outcome

\section{Introduction}

The rate of ambulatory surgical procedures is limited by severe postoperative pain ${ }^{1}$. After particularly painful surgical procedures, moderate to severe pain is estimated to occur in approximately $30 \%$ of patients.
Correspondence to: Kata Sakic, MD, PhD, Professor Tenured, Department of Anaesthesiology and Pain therapy at Maxillofacial, General, Plastic, Reconstructive and Aesthetic Surgery Polyclinic "Bagatin", Zagreb, Croatia

E-mail:ksakic@mef.hr 
Inadequate analgesia may delay or prevent discharge, or result in readmission. Severe postoperative pain also causes extreme discomfort and can cause sleep disorders, thus contributing to postoperative fatigue. Moreover, postoperative pain limits mobility at home and delays the return to normal activities. The development of effective analgesia for postoperative pain is therefore a priority of modern medicine ${ }^{2,3}$.

Day surgeries are becoming routine for many surgical procedures. However, the degree to which patients need help with pain management at home, following rhinoplasty procedure, mammoplasty, liposuction and abdominoplasty, or face lifting ambulatory day surgery, has received minimal examination. For all patients, most unpleasant 24-hour pain was reported as moderate to severe at all time periods ${ }^{4}$. One of the goals in postoperative pain relief is prevention rather than treatment of pain. When local infiltration analgesia (LIA) is performed before surgical procedure, and multimodal analgesia, including the use of anaesthetics, the attempts to avoid the prescription of single strong opioids postoperatively is significant. The use of non-steroidal anti-inflammatory drugs (NSAID) plus an anaesthetic perioperatively has also been shown to be more effective than anaesthetic alone ${ }^{3}$.

Regional techniques cure pain near its cause, close to damaged tissue area ${ }^{5}$. When local anaesthetics (LA) are used, they provide analgesia without opioid-like side effects.

Importance of rapid response system in day surgery is an estimation of the impact of measurement of vital cardiovascular function in the prevention of postoperative cardiopulmonary complications ${ }^{6}$. Vomiting and nausea after surgery in daytime anaesthesia and surgery is an unpleasant postoperative complication that postpones the discharge of the patient. It is important to apply prevention measures and therapeutic procedures and select the type of remedy for general anaesthesia that will reduce the frequency of vomiting. This article has a goal of assessing the influence of LIA with levobupivacaine on the trend of acute postoperative pain in individuals that underwent surgical rhinoplasty procedure and abdominal surgery that took place in "Bagatin" Polyclinic in Zagreb.

\section{Methods}

This randomised clinical study included 60 participants admitted at the "Bagatin" Polyclinic due to elec- tive surgical procedures in the time period between 01.01.2014. and 01.01.2017. Polyclinic's ethics committee approval was obtained and patients read and signed the informed consent after the study has been clearly explained to them.

The patients were divided into two groups. For each group patients were randomly assigned by www. randomizer.org. First group consisted of 30 patients with indications for rhinoplasty. The second group consisted of 30 patients with abdominal liposuction indications.

Retrospective data was collected from the documentation of 60 patients, such as body weight, age, gender, smoking, allergy, laboratory tests, serum potassium levels in patients on diuretics treatment or those with cardiac arrhythmias, analysis of coagulation tests for evaluation of perioperative haemorrhage, type of procedure, ASA assessment, previous complications, pain medications, duration of surgery and postoperative vomiting. The frequency and connectivity of deviations from clinical and laboratory findings and unwanted events were measured.

Thirty patients undergoing rhinoplasty procedure were assigned to receive preincisional local infiltration analgesiain general anesthesia (Propofol, Rocuronium and Sevoflurane). They received $6 \mathrm{ml}$ of Levobupivacaine $0.25 \%$.

Second group of 30 patients undergoing abdominal liposuction and abdominoplasty also were in general anaesthesia. LIA was used as a single shoot before closure of abdominal wall after resection of skin and subcutaneous fat. Infiltration has been done with $40 \mathrm{ml}$ of $0.25 \%$ bupivacaine. Liposuction solution contains: $1000 \mathrm{ml} 0.9 \% \mathrm{NaCl}, 2 \%$ Lidocaine $50 \mathrm{ml}, 10 \mathrm{ml}$ $\mathrm{NaHCO}_{3}$ (1-mol. solution) and Lipofilling solution contains: $1000 \mathrm{ml} 0.9 \% \mathrm{NaCl}, 2 \%$ Lidocaine $25 \mathrm{ml}, 10$ $\mathrm{ml} \mathrm{NaHCO}$ (1- mol. solution), Suprarenin $1 \mathrm{ml}$.

Postoperative blood pressure, heart rate, breathing frequency and peripheral oxygen saturation were measured every half an hour before patient's discharge, and diuresis, mobilisation, nausea and vomiting were assessed as well.

Visual Analogue Scale scores (0-10) were evaluated every 30 min and 1, 3 and 6 hours postoperatively and the need for rescue analgesic treatment in the first $24 \mathrm{~h}$ for all patients was recorded as well.

The statistics data are shown in tables and figures. The data for descriptive variables were analysed by chi- 
Table 1. Age-related comparison of abdominoplasty and rbinoplasty: chi $i^{2}$ test.

\begin{tabular}{|c|c|c|c|c|}
\hline & & \multicolumn{2}{|l|}{ Age } & \multirow[t]{2}{*}{$\mathrm{P}^{*}$} \\
\hline & & $20-39$ years & $\geq 40$ & \\
\hline Group & $\begin{array}{l}\text { Abdominoplasty } \\
\text { Rhinoplasty }\end{array}$ & $\begin{array}{l}12(40.0) \\
26(86.7)\end{array}$ & $\begin{array}{l}18(60.0) \\
4(13.3)\end{array}$ & \multirow[t]{2}{*}{$<0.001$} \\
\hline \multicolumn{2}{|l|}{ Sum } & $38(63.3)$ & $22(36.7)$ & \\
\hline
\end{tabular}

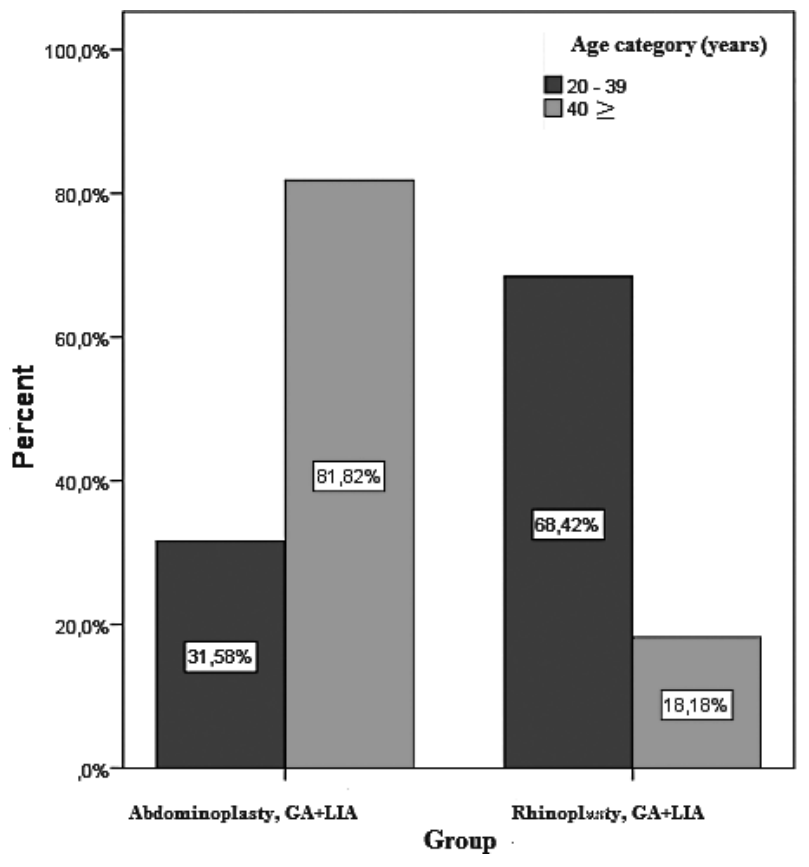

Figure 1. Graphical presentation of age related choice of surgical procedure.

GA- general anaesthesia; LIA- local infiltration analgesia

square test, differences in quantitative variables were tested by Mann-Whitney $\mathrm{U}$ test and Fisher exact test. $\mathrm{P}<0.05$ was considered as statistically significant. Statistical analysis was performed by the IBM SPSS Statistics for Windows 23.

\section{Results}

The collected results showed that a $68.33 \%$ of participants were American Society of Anesthesiologists (ASA) physical status I. The occurrence of acute postoperative pain has been observed in all participants. An additional analgesics dose in the first postoperative day was noted in $85 \%$ of those who underwent an abdominal liposuction and abdominoplasty procedure while $45 \%$ of participants who underwent nasal surgery were provided with analgesics as well. Patients who underwent abdominoplasty were discharged from polyclinic within 48 hours, while those patients who underwent nasal surgery were discharged on the same day of the surgery.

Results showed that $87 \%$ of patients deciding for aesthetic surgery are between $20-39$ years. $68.42 \%$ of rhinoplasty patients were between 20-39 years old, while $81.82 \%$ of abdominoplasty patients 40 years old or older opted for abdominoplasty procedure. $(\mathrm{P}<0.001)$ (Table 1, Fig.1).

$26.7 \%$ male participants and $73.3 \%$ female participants chose aesthetic surgery, such as rhinoplasty and abdominoplasty surgical procedure (Table 2.).

Study results showed that younger people with lower body mass index (BMI) and normal weight, chose nasal surgery, whereas abdominoplasty was chosen by older people who had higher BMI's who were overweight. Candidates that were indicative for the information of distended stomach were given prophylactic antiemetic (Ondansetron, Metoclopramide, Tietilperazin). The patients in for longer surgical procedures received prophylactic antiemetic drugs Ondansetron (88.9\%) and Metoclopramide (80.0\%). Postoperative nausea and vomiting were recorded exclusively amongst the female participants. Haematocrit and haemoglobin levels were significantly higher in male patients. Participants who experienced postoperative vomiting were female $(\mathrm{P}=0.042)$, although when considering age and surgical procedure as well as surgery duration and BMI, participants did not differ significantly (Table 3 ).

Pain and notable nausea had not been present in preoperative period, while amongst participants who mentioned pain or nausea, there were more patients who felt pain sensations after rhinoplasty and 
Table 2. Sex-related comparison of abdominoplasty and rhinoplasty: chi $i^{2}$ test.

\begin{tabular}{|l|l|l|l|l|}
\hline \multicolumn{2}{|c|}{} & Sex & Sum \\
\hline \multirow{2}{*}{ Group } & Abdominoplasty & Male & Female & \\
\hline Sum & Rhinoplasty & $8(26.7)$ & $22(73.3)$ & $30(100.0)$ \\
& & $16(26.7)$ & $22(73.3)$ & $30(100.0)$ \\
\hline
\end{tabular}

Table 3. Patient's characteristics related to postoperative nausea and vomiting.

\begin{tabular}{|l|l|l|l|l|}
\hline \multicolumn{2}{|l|}{ Number of participants (\%) } & \multicolumn{2}{l|}{ Postoperative vomiting } & \multirow{2}{*}{ P } \\
\cline { 3 - 4 } \multicolumn{2}{|l|}{} & Yes & No & \\
\hline Sex & Male & $0(0.0)$ & $16(32.7)$ & \multirow{2}{*}{$\mathbf{0 . 0 4 2}$} \\
& Female & $9(100.0)$ & $33(67.3)$ & \\
\hline Age (years) & $20-39$ & $5(55.6)$ & $31(63.3)$ & \multirow{2}{*}{0.718} \\
& $\geq 40$ & $4(44.4)$ & $18(36.7)$ & \\
\hline Surgery duration (hours) & $0-3.99$ & $1(11.1)$ & $11(22.4)$ & \multirow{2}{*}{0.668} \\
& $>4$ & $8(88.9)$ & $38(77.6)$ & \\
\hline BMI & Underweight $(<20)$ & $0(0.0 \%)$ & $3(6.1)$ & \\
& NormalBW $(20-25)$ & $7(77.8)$ & $26(53.1)$ & \multirow{2}{*}{0.754} \\
& Overweight TT(25-30) & $1(11.1)$ & $13(26.5)$ & \\
& Obese $(>30)$ & $1(11.1)$ & $7(14.3)$ & \\
\hline Sum & $9(100.0)$ & $49(1000)$ & \\
\hline
\end{tabular}

BMI - body mass index, BW - body weight

Table 4. Presence of postoperative pain and nausea correlation to the surgical procedure.

\begin{tabular}{|l|l|l|l|l|}
\hline $\begin{array}{l}\text { Surgical } \\
\text { procedure }\end{array}$ & $\begin{array}{l}\text { Pain \% } \\
\text { VAS }>1\end{array}$ & $\begin{array}{l}\text { Pain } \\
\text { free } \% \\
\text { VAS }<1\end{array}$ & $\begin{array}{l}\text { Nausea } \\
\%\end{array}$ & $\begin{array}{l}\text { Non } \\
\text { nausea \% }\end{array}$ \\
\hline $\begin{array}{l}\text { Abdominoplasty } \\
\text { Rhinoplasty }\end{array}$ & 13 & 87 & 27 & 73 \\
\hline
\end{tabular}

VAS - Visual Analogue Scale patients who underwent abdominoplasty had nausea (Table 4).

Comparison of assessed vital functions before and after surgery did not reveal significant differences in mean values but the values of pressure and saturation were slightly lower after the surgical treatment, which were timely monitored and corrected by fluid replacement and early oxygen mask application immediately after surgery.

Table 5. Arterial pressure correlation to postoperative vomiting: Mann-Whitney U test.

\begin{tabular}{|l|l|l|l|}
\hline \multirow{3}{*}{ Characteristic } & \multicolumn{2}{|l|}{ Median (interqurtile range) } & \multirow{2}{*}{$\mathrm{P}^{*}$} \\
\cline { 2 - 3 } & $\begin{array}{l}\text { Vomited } \\
(\mathrm{n}=10)\end{array}$ & $\begin{array}{l}\text { Not vomited } \\
(\mathrm{n}=50)\end{array}$ & 0.36 \\
\hline SBP before surgery & $110.0(105.0-117.0)$ & $115.0(105.0-130.0)$ & 0.23 \\
DBP before surgery & $75.0(70-75.0)$ & $80.0(70.0-82.0)$ & 0.80 \\
SBP after surgery & $111.5(98.0-135.0)$ & $110.5(100.0-128.0)$ & 0.85 \\
DBP after surgery & $70.0(67.0-85.0)$ & $75.0(69.0-80.0)$ & \\
\hline
\end{tabular}

$\mathrm{SBP}=$ systolic blood pressure $\mathrm{DBP}=$ diastolic blood pressure 
Table 6. Characteristics of anaesthesia techniques and comparison of postoperative pain level.

\begin{tabular}{|l|l|l|}
\hline & $\begin{array}{l}\text { 30pts in GA\& LIA } \\
\text { for Rhinoplasty }\end{array}$ & $\begin{array}{l}\text { 30pts in GA\& LIA } \\
\text { for Abdominoplasty }\end{array}$ \\
\hline Postoperative VAS; 30 min (mean, min-max) & 0 & 0 \\
\hline Postoperative VAS; 1h (mean, min-max) & $\mathbf{0 ( 0 - 2 )}$ & $\mathbf{3 ( 1 - 4 )}$ \\
\hline Postoperative VAS; 3h (mean, min-max) & $\mathbf{0 , 5 ( 0 - 2 )}$ & $\mathbf{4 ( 1 - 6 )}$ \\
\hline Postoperative VAS; 6h (mean, min-max) & $\mathbf{1 ( 0 - 2 )}$ & $\mathbf{3 ( 1 - 5 )}$ \\
\hline
\end{tabular}

Pts= patients, GA general anaesthesia, LIA local infiltration analgesia

No significant correlations were found between vomiting after surgery and arterial blood pressure before and after surgery (Table 5).

In patients with rhinoplasty procedure VAS scores were lower and in patients with abdominoplasty surgery procedure VAS scores were higher, indicating the difference in the performed surgical procedures depending on the anatomical surgery location (Table 6).

\section{Discussion}

Successful ambulatory surgery is dependent on analgesia that is effective, has minimal adverse effects, and can be safely managed by the patient at home after discharge. Postoperative pain is the most commonly reported complication of ambulatory surgery. Any pain management technique should be effective, safe, simple and inexpensive and many of local anaesthetics seem to qualify on these terms ${ }^{1,7}$.

In this study most of the participants in day surgery were ASA status I, which suggests they were young and healthy. The preoperative assessment confirmed that the patients who underwent surgical treatment in general anaesthesia suffered from nausea and vomiting, especially women of increased body weight and while longer surgical procedures were performed. By choosing to apply a combination of LIA with general anaesthesia in individuals who underwent rhinoplasty procedure or abdominoplasty and liposuction, taking into consideration a number of applied analgesics, the postoperative pain is not intense. Postoperative complications, acute pain, nausea and vomiting are not frequent and intense meaning that as such they do not prolong the postoperative stay in day surgery. Assessing vital functions reduces the frequency of unwanted events and postoperative complications. In day surgery, the need for urgent interventions and moving to intensive care units is reduced, but the Rapid Respon- se System teaches us about the importance of rapid reaction.

Postoperative analgesia in nasal surgery with local infiltration of levobupivacaine in addition to general anaesthesia was significantly more potent and longer lasting without nasal dyspnoea in rhinoplasty procedure. Conventional NSAIDs in combination with paracetamol, administered in time to provide sufficient analgesia in the early recovery period, are optimal.

After waking from general anaesthesia we noticed patients' pain was reduced in the abdominal wall and in the wound area around the umbilicus and in the lower abdominal scar. NSAIDs in combination with paracetamol can provide sufficient analgesia, but weak opioids are recommended for moderate pain, and strong opioids for severe pain, on request.This has been the reason patients have been more active immediately in postoperative period and their discharge was faster.

During the second postoperative day patients who underwent nasal procedure did not require analgesics, while only $3 \%$ of patients who underwent an abdominoplasty procedure required an additional dose of analgesics. The research has shown acute postoperative pain manifestation did not lead to a prolonged stay in day surgery facility.

Approximately $64 \%$ of patients have not mentioned any of the unwanted events like prickliness or irritation, prolonged loss of sensation, dyspnoea, headache, sleepiness, rash or obstipation, whilst other $36 \%$ had vomited.

Preoperative LIA provides excellent postoperative analgesia for a limited period and is increasingly preformed in day surgery facilities. LIA allows early patient discharge following at some extent painful surgical procedures that would otherwise require overnight hospitalisation ${ }^{8,9,10,11}$. 
LIA with long-acting local anaesthetics may be safely used in the ambulatory setting with a high degree of efficacy and satisfaction. This technique is associated with rare incidence of neurologic complications and injuries after discharge $\mathrm{e}^{12,13}$.

There are reports about effective pain relief using continuous wound instillation (CWI) after ambulatory surgery. The most promising are reports about CWI after inguinal hernia repair where continuous wound instillation provided sufficient pain relief. Depending on the surgical technique, catheters can be placed subfascially or suprafascially ${ }^{14}$. CWI has been reported to be a successful technique for postoperative pain relief after other different surgical procedures: maxillofacial surgery, breast augmentation, hand surgery ${ }^{15}$.

Successful ambulatory surgery depends on analgesia that is effective, has minimal adverse effects, and can be safely managed by the patient at home after discharge. Postoperative pain is the most commonly reported complication of ambulatory surgery. Although the number of analgesic techniques seems more limited in outpatient than in inpatient surgery, the combination of LIA and NSAIDs or paracetamol of analgesic regimens in a multimodal approach may improve postoperative analgesia and functional outcome after ambulatory surgery ${ }^{16.17}$.

\section{Conclusions}

We conclude postoperative analgesia in day surgery after different procedures with local infiltration of levobupivacaine in addition with general anaesthesia was significantly more potent and longer lasting than that achieved by only general anaesthesia. Part of multimodal approach, local anaesthetic techniques as LIA provide effective postoperative analgesia with conventional NSAIDs in combination with paracetamol, administered in time to provide sufficient analgesia in the early recovery period, are optimal with little adverse effects.

\section{Acknowledgements}

The authors thank the Medical Staff of "Bagatin" Polyclinic and the students (Farah Al-Khazae, Matea Sarka, Ema Šaić and Marijana Grden) of Faculty of Dental Medicine and Health Osijek for their support and assistance.

\section{References}

1. Rawal. N. Current issues in postoperative pain management. Eur J Anesthesiol. 2016;33:160-71. https://doi.org/10.1097/ EJA. 0000000000000366

2. Pavlin DJ, Chen C, Penaloza DA, Polissar NL, Buckley FP. Pain as a factor complicating recovery and discharge after ambulatory surgery. Anesth Analg. 2002;95:627-34.

3. Chauvin M. State of the art of pain treatment following ambulatory surgery. Eur J Anaesthesiol Suppl. 2003;28:3-6.

4. McGrath B, Elgendy H, Chung F, Kamming D, Curti B, King $\mathrm{S}$. Thirty percent of patients have moderate to severe pain $24 \mathrm{hr}$ after ambulatory surgery: a survey of 5,703 patients. Can J Anaesth. 2004;51:886-91.

5. Borodulin VG, Filimonov SV. The blockade of sphenopalatine ganglion through the palatal approach in the present-day rhinological practice. Vestn Otorinolaringol. 2016;81:38-41. https://doi.org/10.17116/otorino201681438-41

6. Petersen JA, Rasmussen LS, Rydahl-Hansen S.Barriers and facilitating factors related to use of early warning score among acute care nurses: a qualitative study. BMC Emerg Med. 2017;17:36. https://doi.org/10.1186/s12873-017-0147-0

7. Klein SM, Buckenmaier CC, III. Ambulatory surgery with long acting regional anesthesia. Minerva Anestesiol 2002;68: 833-41.

8. Kakagia DD, Fotiadis S, Tripsiannis G, Tsoutsos D. Postoperative analgesic effect of locally infiltrated levobupivacaine in fleur-de-Lys abdominoplasty. Aesthetic Plast Surg. 2007;31: 128-32.

9. Abo-Zeid MA, Al-Refaey AK, Zeina AM. Surgically-assisted abdominal wall blocks for analgesia after abdominoplasty: A prospective randomized trial. Saudi J Anaesth. 2018;12:593-8. https://doi.org/10.4103/sja.SJA_303_18

10. Demiraran Y, Ozturk O, Guclu E, Iskender A, Ergin MH, Tokmak A. Vasoconstriction and analgesic efficacy of locally infiltrated levobupivacaine for nasal surgery. Anesth Analg. 2008;106:1008-11, table of contents. https://doi.org/10.1213/ ane.0b013e31816174c3

11. Mohamed AA, Safan TF, Hamed HF, Elgendy MAA. Tumescent Local Infiltration Anaesthesia for Mini Abdominoplasty with Liposuction. Maced J Med Sci. 2018;6:2073-8. https:// doi.org/10.3889/oamjms.2018.475

12. Vintar N, Pozlep G, Rawal N, Godec M, Rakovec S. Incisional self-administration of bupivacaine or ropivacaine provides effective analgesia after inguinal hernia repair. Can J Anaesth. 2002;49:481-6.

13. Popadyuk VI, Kastyro IV, Ermakova NV, Torshin VI. Septoplasty and tonsillectomy: acute stress response as a measure of effectiveness of localanesthetics. Vestn Otorinolaringol. 2016; 81:7-11. https://doi.org/10.17116/otorino20168137-11

14. Moiniche S, Jorgensen H, Wetterslev J, Dahl JB. Local anesthetic infiltration for postoperative pain relief after laparoscopy: a qualitative and quantitative systematic review of intraperitoneal, port-site infiltration and mesosalpinx block. Anesth Analg. 2000;90:899-912. 
15. Fredman B, Zohar E, Tarabykin A, Shapiro A, Mayo A, Klein $\mathrm{E}$ et al. Bupivacaine wound instillation via an electronic patient-controlled analgesia device and a double-catheter system does not decrease postoperative pain or opioid requirements after major abdominal surgery. Anesth Analg. 2001;92:189-93.
16. Rawal N, Axelsson K, Hylander J, Allvin R, Amilon A, Lidegran $\mathrm{G}$ et al. Postoperative patient-controlled local anesthetic administration at home. Anesth Analg. 1998;86:86-9.

17. Šakić K. Organizing the acute pain service in Croatia - How to start? Liječ Vjesn 2005; 127; (Supl.2) 67-72.

Sažetak

\title{
USPOREDBA UČINAKA LOKALNE INFILTRACIJSKE ANALGEZIJE U RAZLIČITIH KIRURŠKIH ZAHVATA U DNEVNOJ KIRURGIJI
}

\author{
K. Šakic, D. Bagatin, T. Bagatin, L. Šakic, V. Jeleč i A. Včev
}

Svrha studije je procjena djelovanja lokalne infiltracijske analgezije (LIA) s levobupivakainom na promjene akutne poslijeoperacijske boli i ishod za pacijente podvrgnute rinoplastici i abdominoplastici u općoj anesteziji.

Istraživanje je provedeno na 60 pacijenata, od kojih je 30 pacijenta bilo podvrgnuto abdominoplastici i 30 pacijenata podvrgnuto rinoplastici sa LIA u općoj anesteziji u Poliklinici Bagatin u vremenskom periodu od 01.01.2014. i 01.01.2017. U $85 \%$ bolesnika podvrgnutih abdominoplastici zabilježena je poslijeoperacijska primjena analgetika, te u $45 \%$ bolesnika podvrgnutih rinoplastici. Pacijenti podvrgnuti abdominoplastici otpušteni su iz poliklinike unutar 48 sati nakon kirurškog zahvata, a svi pacijenti koji su podvrgnuti rinoplastici otpušteni su na isti dan kirurškog zahvata. Tijekom prvog poslijeoperacijskog dana bolesnici podvrgnuti rinoplastici nisu imali potreba za analgeticima, dok je u $3 \%$ bolesnika podvrgnutih abdominoplastici bila potrebna dodatna doza analgetika. Rezultati su studije pokazali da uz primjenu LIA-e poslijeoperacijska bol i povraćanje nakon kirurškog zahvata nisu utjecali na duljinu boravka u ustanovi u kojoj je zahvat učinjen.

Ključne riječi: lokalna infltracijska analgezija, rinoplastika, abdominalna kirurgija, dnevna kirurgija, poslijeoperacijska bol, klinički ishod 